\title{
Imported leishmaniasis in the Netherlands from 2005 to 2012: epidemiology, diagnostic techniques and sequence-based species typing from 195 patients
}

A Bart (a.bart@amc.uva.nl)1, P PAM van Thiel ${ }^{2}$, H JC de Vries $^{3}$, C J Hodiamont $^{1}$, T Van Gool ${ }^{1}$

1. Department of Medical Microbiology, section of Parasitology, Academic Medical Center, Amsterdam, the Netherlands

2. Department of Infectious Diseases, Tropical Medicine and AIDS, Academic Medical Center, Amsterdam, the Netherlands

3. Department of Dermatology, Academic Medical Center, Amsterdam, the Netherlands

Bart A, van Thiel PP, de Vries HJ, Hodiamont CJ, Van Gool T. Imported leishmaniasis in the Netherlands from 2005 to 2012 : epidemiology, diagnostic techniques and sequence-based species typing from 195 patients. Euro Surveill. 2013;18(30):pii=20544. Available online: http://www.eurosurveillance.org/ViewArticle. aspx?Articleld $=20544$

Leishmaniasis is an imported disease in the Netherlands. We report data for the period between 2005 and 2012, on clinical presentation, country where leishmaniasis was acquired, and causative species, for 195 civilian and military patients who had travelled abroad. Most patients were affected by cutaneous leishmaniasis $(C L)(n=185$ patients), while visceral leishmaniasis (VL) ( $\mathrm{n}=8$ patients) and mucocutaneous leishmaniasis ( $n=2$ patients) were less frequently observed. All VL patients had been infected in Europe. $\mathrm{CL}$ was mainly acquired in Afghanistan, Surinam, Morocco and Spain. The majority of CL patients consisted of military personnel $(55 \%, 102 / 185), 78$ of whom had been infected during an outbreak in Afghanistan. Parasitological diagnosis was made by a combination of polymerase chain reaction (PCR), microscopy and culture. Compared to a standard of parasitological proof by any method other than the one under consideration, sensitivities of the individual methods ranged from $73 \%$ to $98 \%$. Microscopy was least sensitive, but is fast and cheap. Mini-exon repeat PCR combines high sensitivity and specificity, and allows differentiation between species by sequencing of the PCR product. Eight different species or species complexes were identified, allowing species-specific therapy. Four patients proved infected with Leishmania naiffi, a hitherto rarely described cause of leishmaniasis. In comparison to previous decennia, an increase in cutaneous leishmaniasis was observed in our hospital, both in civilian and military patients who had travelled abroad. This calls for increased awareness among clinicians, availability of diagnostic tests and species-specific treatment guidelines in non-endemic countries.

\section{Introduction}

In non-endemic countries such as the Netherlands, leishmaniasis is an imported disease with increasing numbers of cases, probably due to increased travel to, migration from, and military operations in endemic regions [1-4]. Moreover, in Europe both visceral (VL) and cutaneous leishmaniasis (CL) have started a northward spread to new foci, including northern Italy, central Europe [5], and the Jura region in France [6], resulting in increasing areas where travellers can be exposed.

There are more than a dozen species of Leishmania parasites that can cause a wide spectrum of clinical manifestations, ranging from localised $C L$ and disfiguring mucocutaneous leishmaniasis $(\mathrm{MCL})$ to potentially lethal VL. These clinical manifestations depend on both pathogen and host genetic factors [7]. In the Netherlands, most cases of visceral leishmaniasis are acquired in the south of Europe [2,8]. In contrast, cutaneous leishmaniasis is acquired in Africa, Asia, Europe and the New World (the Americas) [4]. Travel history is often not sufficient for excluding certain species, as different species may coexist in geographical areas, and incubation times may vary widely. Also, patients may travel through several endemic areas with different species requiring different clinical management [9]. Therefore, species determination is of importance for prognosis and correct treatment.

Traditionally, diagnosis was based on microscopical examination of Giemsa stained smears, culture and histopathology of material from suspected leishmaniasis patients. Molecular methods have been introduced more recently, and are generally reported to be at least as sensitive as the combination of microscopy and culture [10]. Polymerase chain reaction (PCR)-based methods allow correct species discrimination by identification of the PCR amplicon by restriction fragment length polymorphism analysis [11] or sequencing [12].

Leishmaniasis is not a notifiable disease in the Netherlands, which hampers surveillance. The Academic Medical Center of the University of Amsterdam serves as a referral centre for leishmaniasis in our country. Therefore, our data may serve as an approximation for the leishmaniasis incidence in the Netherlands as a whole [4]. We here report the 
changing epidemiology of imported leishmaniasis in 195 patients in the Netherlands in the period from 2005 to 2012. Moreover, we compared diagnostic techniques, and present the results of mini-exon repeat sequence typing of causative species.

\section{Methods}

\section{Patients}

A total of 195 patients for whom the parasitological diagnosis $\mathrm{CL}, \mathrm{MCL}$ or $\mathrm{VL}$ was made at the Academic
Medical Center in the period between June 2005 and December 2012 were included for this study. 180 patients were seen at the outpatient clinics of Dermatology or Tropical Medicine at the Academic Medical Center while 15 patients were seen in other hospitals. For the latter, data on travel were limited for this report. Demographic and clinical data of all 195 patients were aggregated in a database, including age, sex, areas visited, results of culture, impression smear, $P C R$ and sequencing. Suspected country of acquisition

\section{TABLE 1}

Number of imported laboratory-confirmed leishmaniasis patients according to clinical presentation and suspected country of acquisition, Academic Medical Center, University of Amsterdam, the Netherlands, 2005-2012 (n=195)

\begin{tabular}{|c|c|c|c|}
\hline \multirow{2}{*}{ Continent and country of acquisition } & \multicolumn{3}{|c|}{$\begin{array}{l}\text { Clinical presentation } \\
\text { Total patients }{ }^{a} \text { (military patients) }\end{array}$} \\
\hline & cutaneous & mucocutaneous & visceral \\
\hline Europe & $19(0)$ & $0(0)$ & $6(0)$ \\
\hline France & $1(0)$ & $0(0)$ & $1(0)$ \\
\hline Italy & $1(0)$ & $0(0)$ & $1(0)$ \\
\hline Malta & $1(0)$ & $0(0)$ & $0(0)$ \\
\hline Portugal & $1(0)$ & o (o) & o (o) \\
\hline Spain & $13(0)$ & o (o) & $2(0)$ \\
\hline Southern Europe ${ }^{b}$ & $2(0)$ & $0(0)$ & $2(0)$ \\
\hline Asia & $98(86)$ & o (o) & o (o) \\
\hline Afghanistan & $88(86)$ & $0(0)$ & o (o) \\
\hline Iran & $1(0)$ & $0(0)$ & $0(0)$ \\
\hline Iraq & $1(0)$ & $0(0)$ & $0(0)$ \\
\hline Israel & $3(0)$ & o (o) & o (o) \\
\hline Jordan & $2(0)$ & o (o) & o (o) \\
\hline Pakistan & $1(0)$ & o (o) & $0(0)$ \\
\hline Saudi Arabia & $1(0)$ & o (o) & o (o) \\
\hline Syria & $1(0)$ & o (o) & o (o) \\
\hline Africa & $17(0)$ & $\mathrm{o}(0)$ & $0(0)$ \\
\hline Eritrea & $1(0)$ & $0(0)$ & $0(0)$ \\
\hline Kenya & $1(0)$ & o (o) & o (o) \\
\hline Morocco & $15(0)$ & $0(0)$ & $0(0)$ \\
\hline The Americas & $46(16)$ & $2(0)$ & $0(0)$ \\
\hline Belize & $9(9)$ & $0(0)$ & o (o) \\
\hline Bolivia & $1(0)$ & $0(0)$ & $0(0)$ \\
\hline Brazil & $4(0)$ & $0(0)$ & $0(0)$ \\
\hline Costa Rica & $8(0)$ & $0(0)$ & $0(0)$ \\
\hline Peru & $1(0)$ & $0(0)$ & $0(0)$ \\
\hline Suriname & $17(7)$ & $1(0)$ & $0(0)$ \\
\hline Central and south Americab & $6(0)$ & $1(0)$ & o (o) \\
\hline Multiple continents & $2(0)$ & $0(0)$ & $1(0)$ \\
\hline East Africa/Mediterranean ${ }^{b}$ & $1(0)$ & $0(0)$ & $1(0)$ \\
\hline Mediterranean ${ }^{\mathrm{b}}$ (North Africa/Europe) & $1(0)$ & $0(0)$ & $0(0)$ \\
\hline Not recorded & $3(0)$ & o (o) & $1(0)$ \\
\hline Total & $185(0)$ & $2(0)$ & $8(0)$ \\
\hline
\end{tabular}

a The total number of patients comprises the number of leishmaniasis patients who had travelled abroad as part of the military (which is given in parentheses) and the number of patients who had travelled abroad as civilians.

b These patients visited multiple countries where the causative species is endemic. 
was based on travel history in combination with species typing.

Methods for confirming leishmaniasis species Procedures for parasitological diagnosis by microscopy, culture, mini-exon repeat PCR based on the method of Marfurt et al. [13], or combinations thereof, were previously described [14]. For $C L$ and MCL, two biopsies were taken from the edge of the lesion whereby one was used for culture, and the other for microscopy of a Giemsa stained smear and PCR. For VL, bone marrow was used for PCR, microscopy, or culture. Sequences for species determination were generated by amplification, as detailed earlier, with primer Rme2 as one of the two primers[13], followed by single strand sequencing with primer Rmeseq (5'-ACA GAA ACT GAT ACT TAT ATA GCG TTA GTT-3'). Sequence analysis and comparison was performed using the CodonCode software (CodonCode Corporation, Dedham, MA), using consensus sequences for different species as references. References were composed of previously published sequences $[11,15]$ from GenBank, sequences derived from reference strains, and iteratively added patient sequences. Discrimination between the genotypically highly similar Leishmania braziliensis and $L$. peruviana, and between $L$. infantum and $L$. donovani, is not feasible for the mini-exon. The clinical relevance of such distinction is limited, as preferred treatment in the Netherlands is identical for both species, and only depends on the clinical presentation. Of note, discrimination between these species is impossible or difficult by other targets as well $[16,17]$, and therefore their taxonomic status has been a continuing matter of debate [18]. We therefore refer to these species as $L$. braziliensis/peruviana and $L$. donovani/infantum, respectively. Other species that can be can be discriminated include L. major, L. tropica, L. aethiopica, L. mexicana, L. amazonensis, L. guyanensis, L. panamensis, L. lainsoni, and L. naiffi.

\section{Sensitivity of diagnosis techniques}

Sensitivity of different diagnostic techniques was calculated relative to parasitological evidence of leishmaniasis by at least one other method than the technique under consideration, assuming $100 \%$ specificity of culture, microscopy and PCR each. This is warranted, as stringent measures were used to avoid contamination in PCR [19], and typing by sequence analysis should reveal possible contamination for both PCR and culture.

\section{Results}

\section{Patients}

From June 2005 to December 2012, leishmaniasis was diagnosed and laboratory confirmed in 195 patients. The endemic countries visited and clinical forms of leishmaniasis are listed in Table 1. The vast majority of patients $(95 \%, 185 / 195)$ presented with CL. VL $(\mathrm{n}=8$ patients) and $M C L(\mathrm{n}=2$ patients) were only rarely encountered. Patients consisted of 102 military personnel who had travelled as part of their duties, and 93

\section{FIGURE 1}

Distribution over three time periods of imported laboratory-confirmed cutaneous leishmaniasis patients, according to military or civilian status, and geographical area of infection, Academic Medical Center, University of Amsterdam, the Netherlands, 1999-2012 ( $\mathrm{n}=302)$

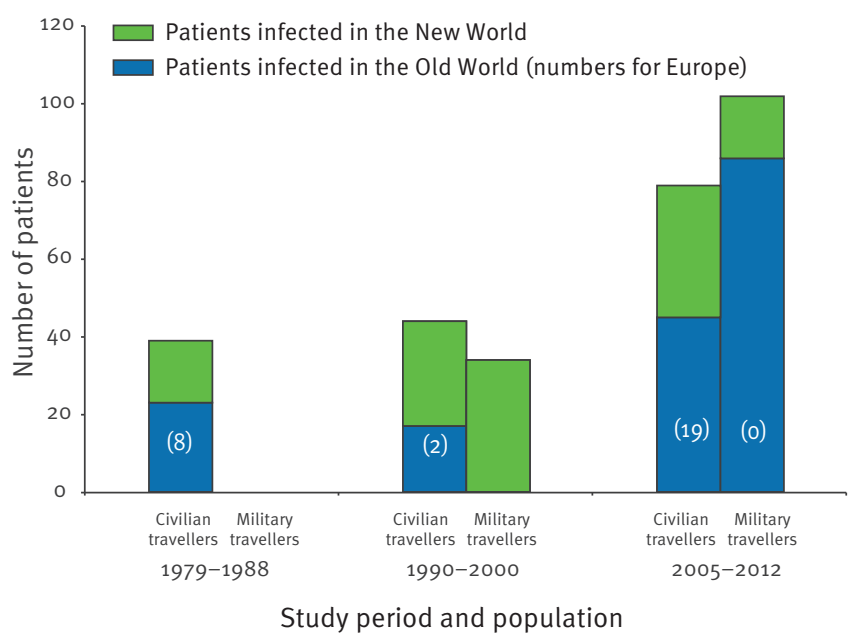

New World refers to the Americas. Old World comprises Africa, Asia and Europe.

civilian patients who had been travelling abroad (which comprise tourists, business travellers and travellers originating from an endemic country visiting family and friends). Median age for military patients, who all had CL, was 24 years (range: 19-50). Median age for civilian patients with $M C L$ was 46 years (range: $2-78$ ), and for travellers with VL 55 years (range: 2-62). The male to female ratio in the total 93 civilian patients was 1.53:1.

A previous study described an increasing incidence of imported $\mathrm{CL}$ in our population in the period from 1990 to 2000 (78 cases) as compared to between 1979 and 1989 (39 cases) [4]. For the current, shorter, study period between 2005 and 2012, the number of detected $C L$ patients was 185 (Figure 1), including 78 military personnel, who had acquired $\mathrm{CL}$ in an outbreak in north Afghanistan [20-22]. Even if the latter are not considered, the 107 remaining patients in the current study represent more patients than in previous periods.

Between 1990 and 2000, most patients acquired CL in the New World $(78 \%, 61 / 78)$. In the present study, more than twice as many patients acquired $\mathrm{CL}$ in the Old World (Europe, Asia and Africa) $(n=136)$ as in the New World $(n=46)$. The number of patients who acquired $C L$ in the Old World was still higher $(n=58)$ when the military patients who had been deployed to north Afghanistan $(n=78)$ were put aside [20-22]. 
Distribution of laboratory-confirmed leishmaniasis imported patients, according to military and civilian status, by month of diagnosis, Academic Medical Center, University of Amsterdam, the Netherlands, 2005-2012 (n=195)

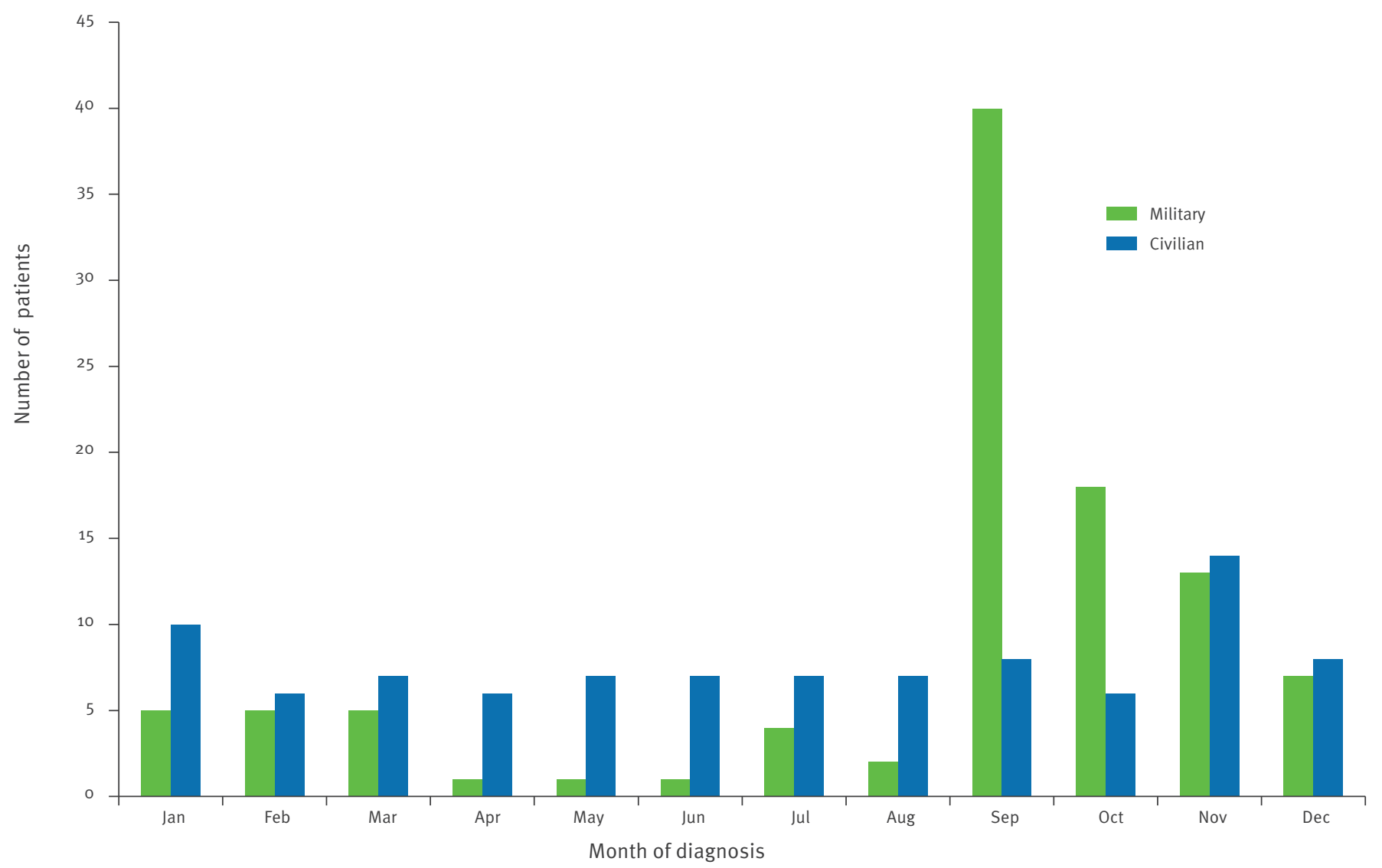

More than half of the total CL patients (102/185) in the present study were military personnel. This constitutes an increase in military personnel with $\mathrm{CL}$ compared to the previous study periods (with a total of 34 cases in 1990-2000 and none in 1979-1988). Most military patients got infected in the Old World in Afghanistan $(n=86)$, whereas infections in the New World were acquired in Belize $(n=9)$ and Suriname $(n=7)$. An increase in imported infected civilian $C L$ patients $(n=83)$, which comprise tourists and business travellers as well as those originating from an endemic country visiting family and friends, was also observed compared to previous studies (44 in 1990-2000 and 39 in 1979-1988), as shown in Figure 1. Most civilian patients who were infected in the New World acquired $\mathrm{CL}$ in Suriname (10 of 30), but by different species than the military patients. Most civilian patients infected in the Old World contracted $\mathrm{CL}$ in various countries in Europe (19 of 48), as was also the case for VL (Table 1).

As shown in Figure 2, the distribution of patients per month is different for military patients when compared to civilian patients. Military patients usually present as groups after duty abroad. In contrast, imported civilian patients present throughout the year with only a relatively small increase towards the end of the year.
Diagnostic methods for cutaneous leishmaniasis and sequence-based typing The sensitivity of PCR, microscopy and culture, and combinations thereof for diagnosis of $\mathrm{CL}$ (including $\mathrm{MCL}$ ), are listed in Table 2.

Sequencing of the mini-exon repeat $P C R$ product obtained from either direct biopsy material or from cultured parasites, allowed identification of the causative species in patients affected with VL, CL or MCL by comparison to consensus sequences. Altogether the species responsible for the disease was identified in 186 of the 195 patients.

\section{Leishmania species distribution according to geographical region of acquisition \\ Eight different species or species groups were detected, three in the Old World and six in the New World (Figure 3).}

In patients infected in the Old World, L. major, L. tropica and L. donovani/infantum were detected. The high number of L. major patients was predominantly found among the Dutch soldiers deployed to Afghanistan. Patients infected in Europe were exclusively infected with $L$. infantum/donovani. In the New World, $L$. 
TABLE 2

Sensitivity of different (combinations) methods for diagnosis of (muco)cutaneous leishmaniasis, Academic Medical Center, University of Amsterdam, the Netherlands, 2005-2012 ( $\mathrm{n}=187$ )

\begin{tabular}{|c|c|c|c|c|}
\hline Diagnostic methods & Positive & Negative & $N^{a}$ & Sensitivity \\
\hline $\mathrm{PCR}^{\mathrm{b}}$ & 183 & 4 & 0 & $98 \%$ \\
\hline Microscopy & 127 & 47 & 13 & $73 \%$ \\
\hline Culture & 138 & 29 & 20 & $83 \%$ \\
\hline Microscopy and/or culture ${ }^{c}$ & 151 & 15 & 21 & $91 \%$ \\
\hline Microscopy and/or PCR & 172 & 2 & 13 & $99 \%$ \\
\hline Culture and/or PCR & 164 & 2 & 21 & $99 \%$ \\
\hline Microscopy, culture and/or PCRc & 166 & 0 & 21 & $100 \%$ \\
\hline
\end{tabular}

ND: not determined; PCR: polymerase chain reaction.

a These samples represent either requests from other hospitals or patients for which no biopsy was taken for culture due to the small size of the lesion.

b Mini-exon repeat PCR based on the method of Marfurt et al [13].

Patients for whom not all methods were performed were included in the group labelled as ND.

guyanensis was most prevalent (Figure 3), and mainly found among patients that visited Suriname (Table 1).

\section{Leishmania species distribution among civilian and military travellers}

The species distribution differed markedly between military and civilian patients, with L. tropica, L. panamensis and $L$. donovani/infantum exclusively found in civilian patients, and $L$. naiffi only in military patients (Table 3). This difference reflects the endemic countries visited, as military patients acquired leishmaniasis in Afghanistan $(n=86)$, Belize $(n=9)$ and Suriname $(n=7)$. For the latter country, infection with $L$. naiffi has been related to different epidemiological circumstances during military manoeuvres [14].

\section{Discussion}

Visceral and cutaneous leishmaniases are imported diseases in the Netherlands. The cases of VL are mostly imported from countries in southern Europe, as confirmed in our study where all VL patients were civilians who had been infected there. Also among the 83 civilian CL patients, 19 (23\%) of the CL infections were acquired in Europe, with 13 in Spain. This is noteworthy, as misdiagnosis, due to the misconception that leishmaniasis is a tropical disease, has occurred in the Netherlands for cases acquired in southern Europe [8]. CL for civilians and military combined was mainly acquired in Afghanistan, Suriname, Morocco and Spain (Table 1). Our data show an increase in patients diagnosed with CL in our hospital between 2005 and 2012 compared to the periods from 1979 to 1988 and 1990 to 2000 [4] (Figure 1). An analysis of nationwide pathological records from 1996 to 2007 found an increase during that period as well [2]. Comparison of the pathological data available only until 2007 [2] to our data shows that our patient population represented $56 \%$ (39/70) of the CL cases in 2006 and 45\% (14/31) in 2007 in the

\section{FIGURE 3}

Distribution of Leishmania species derived from leishmaniasis patients according to geographical region of infection, Academic Medical Center, University of Amsterdam, the Netherlands, 2005-2012 (n=183)

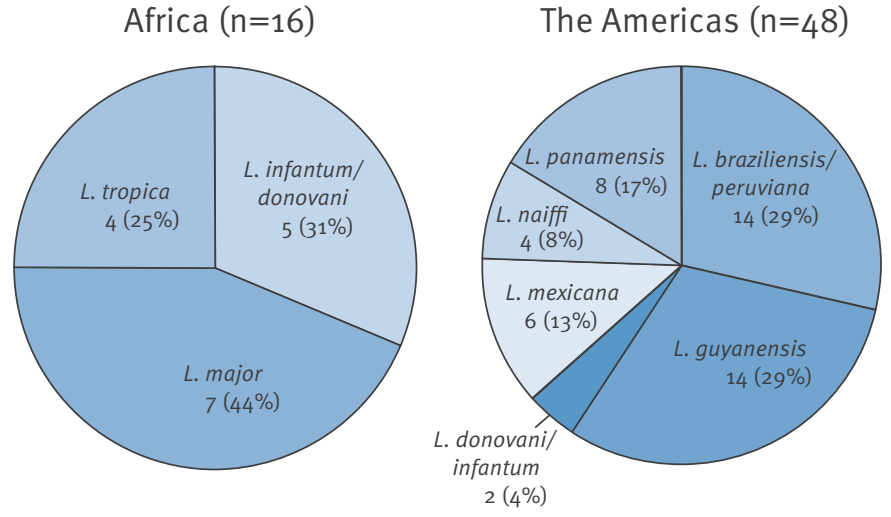

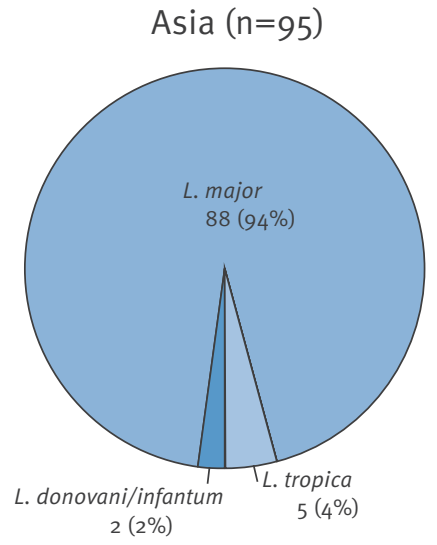

$2(2 \%)$

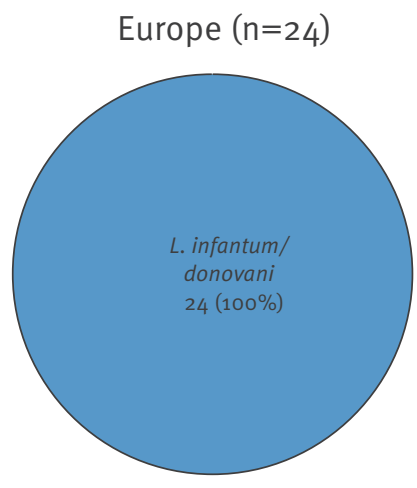


Causative Leishmania species identified in military and civilian populations, Academic Medical Center, University of Amsterdam, the Netherlands, 2005-2012 ( $\mathrm{n}=195)$

\begin{tabular}{|c|c|c|c|c|}
\hline \multirow{2}{*}{ Species } & \multicolumn{2}{|c|}{ (Muco)cutaneous } & \multirow{2}{*}{$\begin{array}{c}\text { Visceral } \\
\text { civilian }\end{array}$} & \multirow{2}{*}{ Total } \\
\hline & military & civilian & & \\
\hline L. braziliensis/peruviana & 5 & $9^{a}$ & 0 & 14 \\
\hline L. donovani/infantum & 0 & 29 & 8 & 37 \\
\hline L. guyanensis & 3 & $11^{\text {a }}$ & 0 & 14 \\
\hline L. major & $77^{\mathrm{b}}$ & 14 & 0 & 91 \\
\hline L. mexicana & 4 & 2 & 0 & 6 \\
\hline L. naiffi & 4 & 0 & 0 & 4 \\
\hline L. panamensis & 0 & 8 & 0 & 8 \\
\hline L. tropica & 0 & 12 & 0 & 12 \\
\hline$N^{c}$ & 9 & 0 & 0 & 9 \\
\hline Total & 102 & 85 & 8 & 195 \\
\hline
\end{tabular}

a Of these patients, one patient presented with mucocutaneous disease due to L. braziliensis and one due to L. guyanensis.

These patients belonged to troops deployed to north Afghanistan, and were part of a larger outbreak described elsewhere [20-22].

Of these patients, two were positive by microscopy only. Seven patients obtained prior treatment; polymerase chain reaction was weakly positive but yielded insufficient product for sequence analysis in these seven patients.

Netherlands. Therefore, our observations with respect to epidemiology and causative species are probably valid for most patients in the Netherlands.

Part of the increase in cases is due to increased exposure, due to larger numbers of military personnel sent to endemic countries. An increase in imported leishmaniasis is a common problem in non-endemic countries that send troops abroad, both for training and active duty [23-25]. Military patients usually present as groups after duty abroad, and awareness in a unit is high after initial cases are identified. As a result, diagnosis of leishmaniasis patients among military are more clustered in time (Figure 2).

The number of infected civilian travellers increased also as compared to previous years [4] (Figure 1), and patients presented throughout the year (Figure 2). This more evenly spread distribution probably reflects a combination of travel throughout the year, variation in incubation times, health seeking behaviour and variation in delay before referral for diagnosis. Only a relatively small increase towards the end of the year was noted, which is probably the consequence of increased travel during summer.

Apart from increased exposure and possible changes in health seeking behaviour for CL in immigrant communities [26], improved diagnostic methods, and awareness among clinicians may also have contributed to the increased number of leishmaniasis patients detected. During the study period, PCR was a routine diagnostic procedure for leishmaniasis, in contrast to the previous study periods [4]. In the preceding years, both specificity and sensitivity have benefited from improved measures to avoid contamination of PCR [19] and higher quality of reagents and equipment for PCR and DNA extraction. In the present study, sensitivity of PCR was higher (98\%, Table 2 ) as compared to previous years (89\%) [4]. Though PCR alone has a high sensitivity, both microscopy and culture have added value (Table 2). Apart from increasing overall sensitivity, microscopy can be used as point of care test, and results are available within one hour at low cost. Culture allows expansion of strain collections for research purposes, e.g. for quality control programmes and comparison of different typing methods as advocated by the LeishMan consortium [27].

Follow-up of $C L$ is based on clinical evaluation. Only if therapy failure is suspected, are laboratory diagnostics performed. Whole parasites as demonstrated by microscopy, culture, or the detection of Leishmania RNA [28] are considered a sign of relapse. Detection of parasite DNA by PCR is no definitive proof of relapse, since this can also be present in scars of successfully treated patients $[29,30]$.

For accurate treatment and precise prognosis of $\mathrm{CL}$, characterisation of the causative Leishmania species is often needed, e.g. pentamidine is effective for treatment of L. guyanensis but less efficient against disease caused by L. braziliensis [4]. This was accomplished by sequence analysis in the vast majority (95.1\%) of our patients, detecting eight different species or species groups (Figure 3). The species distribution was different between military and civilan patients (Table 3), probably as a result of different endemic countries 
visited and different epidemiological circumstances encountered [14].

The relevance of typing is best illustrated in our population for the $C L$ and $M C L$ patients that were infected in Suriname (Table 1). Because of its historic ties with the Netherlands, Suriname is a popular destination for Dutch tourists, persons visiting friends and relatives, and has been used for jungle training by the Dutch military. Traditionally, L. guyanensis was regarded as the causative species of CL from Suriname. Recently, L. amazonensis, L. lainsoni, L. naiffi, and L. braziliensis have been reported for the first time in Suriname as well $[31,32]$. Awareness that any of these species can be present in patients returning from Suriname is important, as the differences between these species influence clinical management.

In conclusion, the number of imported leishmaniasis patients in our hospital, and probably the Netherlands as a whole, continues to increase. This increase affects both civilian and military patients. Although most patients in this study were infected with $\mathrm{CL}$, however it is noteworthy that all patients with VL had acquired their infection in European endemic countries. CL was also acquired in Europe for approximately $20 \%$ of civilian patients. Among all imported cases, eight different Leishmania species or species groups were identified. Improved diagnostic procedures, including sequencebased typing, allow species-specific treatment.

\section{References}

1. Antinori S, Gianelli E, Calattini S, Longhi E, Gramiccia M, Corbellino M. Cutaneous leishmaniasis: an increasing threat for travellers. Clin Microbiol Infect. 2005;11(5):343-6. http://dx.doi.org/10.1111/j.1469-0691.2004.01046.x PMid:15819858

2. Herremans T, Pinelli E, Casparie M, Nozari N, Roelfsema J, Kortbeek L. Increase of imported leishmaniasis in the Netherlands: a twelve year overview (1996-2007). Int Health. 2010;2(1):42-6.

http://dx.doi.org/10.1016/j.inhe.2009.12.005

3. Schwartz E, Hatz C, Blum J. New world cutaneous leishmaniasis in travellers. Lancet Infect.Dis. 2006;6:342-349 http://dx.doi.org/10.1016/S1473-3099(06)70492-3

4. Zeegelaar JE, Steketee WH, van Thiel PP, Wetsteyn JC, Kager PA, Faber WR. Changing pattern of imported cutaneous leishmaniasis in the Netherlands. Clin.Exp.Dermatol. 2005; 30(1):1-5.

http://dx.doi.org/10.1111/j.1365-2230.2004.01677.x PMid:15663490

5. Aspock H, Gerersdorfer T, Formayer H, Walochnik J. Sandflies and sandfly-borne infections of humans in Central Europe in the light of climate change. Wien.Klin.Wochenschr. 2008;120(19-20 Suppl 4):24-9.

6. Faber WR, Hoekzema R, Bart A, Zeegelaar JE, de Vries HJ. Cutaneous leishmaniasis acquired in Jura, France. Emerg Infect Dis. 2012;18(1):183-4.

http://dx.doi.org/10.3201/eid1801.110408

PMid:22257720 PMCid:PMC3310094

7. Schriefer A, Wilson ME, Carvalho EM. Recent developments leading toward a paradigm switch in the diagnostic and therapeutic approach to human leishmaniasis. Curr Opin Infect Dis. 2008;21(5):483-8. http://dx.doi.org/10.1097/QC0.obo13e32830doee8 PMid:18725797 PMCid:PMC 2593452

8. van Vliet MJ, Veeken H, Hart W, Tamminga RY. [Clinical reasoning and decision-making in practice. A young boy with fever, pancytopenia and an enlarged spleen]. Ned Tijdsch Geneeskd. 2006;150(30):1662-8. Dutch.

PMid:16922351
9. Blum J, Desjeux P, Schwartz E, Beck B, Hatz C. Treatment of cutaneous leishmaniasis among travellers. I Antimicrob Chemother. 2004;53(2):158-66. http://dx.doi.org/10.1093/jac/dkho58 PMid:14729756

10. Faber WR, Oskam L, van GT, Kroon NC, Knegt-Junk KJ, Hofwegen $\mathrm{H}$, et al. Value of diagnostic techniques for cutaneous leishmaniasis. J Am Acad Dermatol. 2003;49(1):704 . http://dx.doi.org/10.1067/mjd.2003.492 PMid:12833011

11. Marfurt I, Niederwieser I, Makia ND, Beck HP, Felger I. Diagnostic genotyping of Old and New World Leishmania species by PCR-RFLP. Diagn Microbiol Infect Dis. 2003; 46(2):115-24. http://dx.doi.org/10.1016/S0732-8893(03)00040-3

12. Requena JM, Chicharro C, Garcia L, Parrado R, Puerta CJ, Canavate $C$. Sequence analysis of the 3 '-untranslated region of HSP70 (type I) genes in the genus Leishmania: its usefulness as a molecular marker for species identification. Parasit Vectors. 2012;5:87. http://dx.doi.org/10.1186/1756-3305-5-87 PMid:22541251 PMCid:PMC3425316

13. Marfurt J, Nasereddin A, Niederwieser I, Jaffe CL, Beck HP, Felger I. Identification and differentiation of Leishmania species in clinical samples by PCR amplification of the miniexon sequence and subsequent restriction fragment length polymorphism analysis. J Clin Microbiol. 2003;41(7):3147-53.

http://dx.doi.org/10.1128/JCM.41.7.3147-3153.2003 PMid:12843055 PMCid:PMC165364

14. van Thiel PP, Gool Tv, Kager PA, Bart A. First cases of cutaneous leishmaniasis caused by Leishmania (Viannia) naiffi infection in Surinam. Am J Trop Med Hyg. 2010;82(4):588-90 http://dx.doi.org/10.4269/ajtmh.2010.09-0360 PMid:20348504 PMCid:PMC2844559

15. Fernandes O, Murthy VK, Kurath U, Degrave WM, Campbell DA. Mini-exon gene variation in human pathogenic Leishmania species. Mol Biochem Parasitol. 1994;66(2):261-71. http://dx.doi.org/10.1016/0166-6851(94)90153-8

16. Lukes J, Mauricio IL, Schonian G, Dujardin JC, Soteriadou K, Dedet JP, et al. Evolutionary and geographical history of the Leishmania donovani complex with a revision of current taxonomy. Proc Natl Acad Sci U S A. 2007;104(22):9375-80. http://dx.doi.org/10.1073/pnas.0703678104 PMid:17517634 PMCid:PMC1890502

17. Fraga J, Montalvo AM, De Doncker S, Dujardin JC, Van der Auwera G. Phylogeny of Leishmania species based on the heatshock protein 70 gene. Infect Genet Evol. 2010;10(2):238-45. http://dx.doi.org/10.1016/j.meegid.2009.11.007 PMid:19913110

18. Banuls AL, Hide M, Prugnolle F. Leishmania and the leishmaniases: a parasite genetic update and advances in taxonomy, epidemiology and pathogenicity in humans. Adv Parasitol. 2007;64:1-109. http://dx.doi.org/10.1016/So065-308X(06)64001-3

19. Aslanzadeh J. Preventing PCR amplification carryover contamination in a clinical laboratory. Ann Clin Lab Sci. 2004;34(4):389-96. PMid:15648778

20. van Thiel PP, van Gool T, Faber WR, Leenstra T, Kager PA, Bart A. Variation in clinical presentation and genotype of causative Leishmania major strain in cutaneous leishmaniasis in north and south Afghanistan. Am J Trop Med Hyg. 2011;85(1):60-3 http://dx.doi.org/10.4269/ajtmh.2011.10-0531 PMid:21734125 PMCid:PMC3122344

21. van Thiel PP, Leenstra T, de Vries HJ, van der Sluis A, van GT, Krull AC, et al. Cutaneous leishmaniasis (Leishmania major infection) in Dutch troops deployed in northern Afghanistan: epidemiology, clinical aspects, and treatment. Am J Trop Med Hyg. 2010;83(6):1295-300. http://dx.doi.org/10.4269/ajtmh.2010.10-0143 PMid:21118937 PMCid:PMC2990047

22. van Thiel PP, Leenstra T, Kager PA, de Vries HJ, van VM, van der Meide WF, et al. Miltefosine treatment of Leishmania major infection: an observational study involving Dutch military personnel returning from northern Afghanistan. Clin Infect Dis. 2010;50(1):80-3.

http://dx.doi.org/10.1086/648726 PMid:19951107

23. Bailey MS. Cutaneous leishmaniasis in British troops following jungle training in Belize. Travel Med Infect Dis. 2011;9(5):253-4. http://dx.doi.org/10.1016/j.tmaid.2011.07.001 PMid:21856236

24. Berger F, Romary P, Brachet D, Rapp C, Imbert P, Garrabe E, et al. [Outbreak of cutaneous leishmaniasis in military population coming back from French Guiana]. Rev Epidemiol Sante 
Publique. 2006;54(3):213-21. French.

http://dx.doi.org/10.1016/S0398-7620(06)76717-7

25. Elston DM, Miller SD. Leishmaniasis acquired in the Iraqi

Theater of Operations: lessons learned. Cutis. 2004;74(4):253-

5 .

PMid:15551719

26. Mohammedamin RS, van der Wouden JC, Koning S, Schellevis FG, van Suijlekom-Smit LW, Koes BW. Reported incidence and treatment of dermatophytosis in children in general practice: a comparison between 1987 and 2001. Mycopathologia.

2007;164(6):271-8.

http://dx.doi.org/10.1007/s11046-007-9062-3

PMid:17891509 PMCid:PMC 2780650

27. European Network for Tropical Medicine and Travel Health

(TropNet). LeishMan - Surveillance of imported leishmaniasis

with regard to diagnostic and therapeutic procedures. Basel: TropNet. [Accessed: 2012]. Available from: http://www.tropnet. net/index.php?id=103

28. van der Meide WF, Schoone GJ, Faber WR, Zeegelaar JE, de Vries HJ, Ozbel Y, et al. Quantitative nucleic acid sequencebased assay as a new molecular tool for detection and

quantification of Leishmania parasites in skin biopsy samples. J Clin Microbiol. 2005;43(11):5560-6.

http://dx.doi.org/10.1128/JCM.43.11.5560-5566.2005

PMid:16272487 PMCid:PMC1287793

29. Mendonca MG, de Brito ME, Rodrigues EH, Bandeira V, Jardim ML, Abath FG. Persistence of leishmania parasites in scars after clinical cure of American cutaneous leishmaniasis: is there a sterile cure? J Infect Dis. 2004;189(6):1018-23. http://dx.doi.org/10.1086/382135 PMid:14999605

30. Schubach A, Haddad F, Oliveira-Neto MP, Degrave W, Pirmez C, Grimaldi G Jr, et al. Detection of Leishmania DNA by polymerase chain reaction in scars of treated human patients. Infect Dis. 1998;178(3):911-4.

http://dx.doi.org/10.1086/515355

PMid:9728572

31. Hu RV, Kent AD, Adams ER, van der Veer C, Sabajo LO, Mans DR, et al. First case of cutaneous leishmaniasis caused by Leishmania (Viannia) braziliensis in Suriname. Am J Trop Med Hyg. 2012;86(5):825-7.

http://dx.doi.org/10.4269/ajtmh.2012.11-0728

PMid:22556081 PMCid:PMC3335687

32. van der Meide WF, Jensema AJ, Akrum RA, Sabajo LO, Lai A Fat RF, Lambregts L. Epidemiology of cutaneous leishmaniasis in Suriname: a study performed in 2006. Am J Trop Med Hyg. 2008;79(2):192-7

PMid:18689623 